\title{
THE SOCIO-ECONOMIC IMPACT OF THE KLEIN KAROO NATIONAL ARTS FESTIVAL (KKNK)
}

\author{
Louwrens van der Merwe* \\ North-West University \\ louwrensvdm@gmail.com
}

\author{
Melville Saayman ${ }^{\dagger}$ \\ North-West University \\ Melville.Saayman@nwu.ac.za
}

\author{
Andrea Saayman ${ }^{\ddagger}$ \\ North-West University \\ Andrea.Saayman@nwu.ac.za.ac.za
}

February 2009

\begin{abstract}
Events and festivals are hosted with the expectation that they hold many benefits for the host communities. These benefits include employment, income generation, and increasing tourist numbers, thereby improving the quality of life of the host community. However, little is known about the socio-economic impact of arts festivals, especially in the South African context. Hence, the purpose of this article was to determine the socio-economic impact of the Klein Karoo National Arts Festival (KKNK) on the community of Oudtshoorn. This festival is the largest arts festival, both in terms of visitor numbers as well as income generation, in South Africa. In order to achieve the goal of the research, three surveys were conducted: firstly, a community survey; secondly, a business survey; and, finally, a visitor survey. The results indicate that the KKNK contributes significantly to the economy and community of Oudtshoorn. From a social point of view, however, the respondents indicated that the festival benefits the community more than the individual. To increase the positive socio-economic outcomes of the KKNK, the festival organisers have to focus on greater participation by, and communication with, all stakeholders, especially the local community.
\end{abstract}

\section{Keywords:}

Socio-economic impact, Klein Karoo National Arts Festival, multiplier analysis, South Africa

\footnotetext{
Mr Louwrens $\mathrm{H}$ van der Merwe is a post-graduate student in Tourism Management at North-West University, South Africa.

† Prof Melville Saayman is a Professor in Tourism at North-West University, South Africa.

‡Prof Andrea Saayman is a Professor in Economics at North-West University, South Africa.
} 


\section{INTRODUCTION}

The Klein Karoo National Arts Festival (abbreviated as KKNK) is an annual arts festival held over eight days during the March/April school holiday in Oudtshoorn, South Africa (Cruywagen, 2002:190). Since the festival's inception in 1995, it has grown into the largest arts festival in terms of productions, income generation, and visitor numbers in South Africa. When the concept for this festival was conceived, two main purposes were identified: to create an event where Afrikaans-speaking people of all races could enjoy the culture and languages of post-apartheid South Africa, and, secondly, to attract money and tourists to Oudtshoorn (see the map in FIGURE 1) so as to create an economic boost to the community (Kitshoff, 2004b:237). The latter provides the rationale for this research. The festival includes visual and performing arts such as cabaret, music theatre, classical music, jazz and popular music, bringing more than 250 productions to stage and including more than 1000 artists (Slabbert, Saayman, Saayman \& Viviers, 2007:7; Oudtshoorn Municipality, 2005/2006:10).

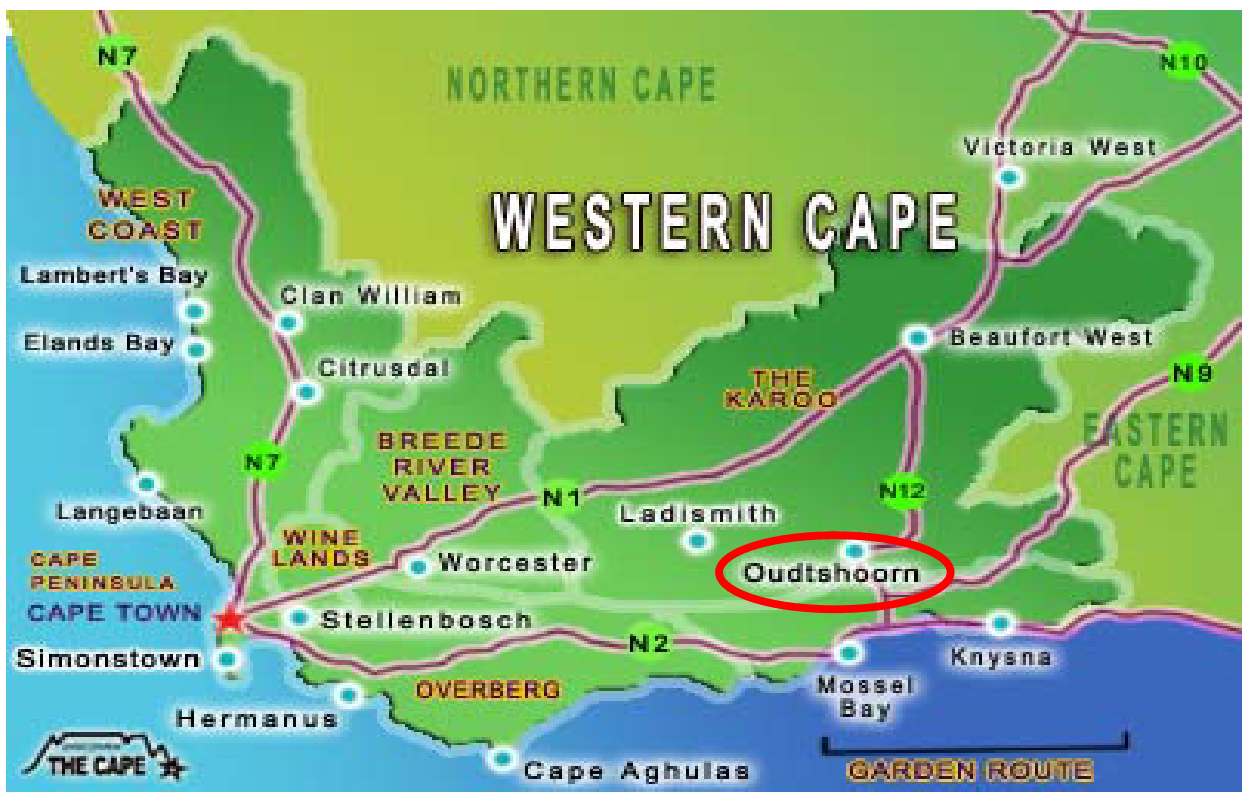

\section{FIGURE 1: Oudtshoorn in the Western Cape, home of the KKNK}

\section{Source: Cape Town accommodation and travel, 2007}

Arts festivals, according to Van der Merwe (2008:23), can be defined as "public celebrations of local arts, traditions, and cultures; combining various forms of visual and performing arts, including painting, fine arts, crafts, drama, film, and all music genres". These celebrations would however not take place without a host community. Getz (1997; as quoted by Quinn, 2006:304), states: "if there were no host community, there could be no festival". This statement stresses the importance of the role of communities in sustaining events. This is highlighted by Kitshoff (2004a:74) and Allen, 0'Toole, Harris, and McDonnell (2008:132), who indicated that members of the community all have different needs, attitudes, and aspirations, which have an influence on the sustainability of an event. Gursoy and Kendall (2006:608), Macleod (2001) and Fauzi and Buchary (2002) add that the community would only support the event or increased 
numbers of tourists if the positive impacts exceed the negatives. Thus, an event's sustainability is highly dependent on community involvement (Gursoy, Jurowski \& Uysal, 2002:80). Levels of community involvement are largely influenced by community perceptions regarding the event and the organisers' effort to include the community (often referred to as the social impact). This is supported in research by Maenning (2007), who investigated the 2006 FIFA Soccer World Cup in Germany. Therefore, the event organiser has to develop effective communication strategies to inform and involve the community in event planning (Allen, et al., 2008:56 and Streuders, 2008).

The benefits generated by events are the reasons why events are becoming more important for communities and destinations: these benefits include infrastructure improvements, job creation, income generation, the improvement of host town identity and image, resident-tourist relations and cultural opportunities, as well as increased community involvement (Shone \& Parry, 2004:54; Auld \& McArthur, 2003:192; Heilbrun \& Gray, 2001:358; Getz, 1997:51; Saayman, 2001:84; Saayman \& Saayman, 2006a:571; Yeoman, Robertson, Ali-Night, Drummond, and Beattie-McMahon, 2004:33; Shone \& Parry, 2004:62). Unfortunately, events also have negative impacts that include local business disruption (leading to financial losses and lower turnovers), price inflation, changes in community identity and image, increases in noise pollution, overcrowding, and substance abuse (Tiyce \& Dimmock, 2000:223-229; Allen, 0’Toole, Harris, \& McDonnell, 2005:31; Dwyer, Mellor, Mistilis, \& Mules, 2000:32). Therefore, it can clearly be seen that events create economic as well as social impacts and play an important role in tourism, as McKercher, Mei and Tse (2006:56-57) suggest. However, Delamere (1998:26, 27) states that most of the so-called socio-economic studies conducted - and this is evident in the literature have focused more on economic than on the social aspects (Kim, Gursoy \& Lee, 2006:86 and Loots, 2006:2). Bowles (1981; as quoted by Glasson \& Heaney, 1993:336) indicated that the essence of a socio-economic impact analysis is the influence that tourism has on the quality of life of the community. The purpose of this article is therefore to determine the socio-economic impact of the KKNK on the host community of Oudtshoorn.

\section{LITERATURE REVIEW}

Socio-economic research studies the link between society and the economy (Anon, 2006) and is undertaken to determine what changes could take place (because of new developments) in the community's social and economic well-being (Edwards, 2000). The main determinants of the magnitude of a festival's economic impact are festival size (referring to the number of ticketed shows), the length of the festival, festinos' (used as a synonym for festival-goer) length of stay, the number of festinos, how much festinos spend, the amount of money received from sponsorships, and the festival's physical location (as this has a great influence on leakages) (Saayman \& Saayman, 2006a:570; Saayman \& Saayman, 2004:638). The latter research partnership also stated that another determinant of the magnitude of the economic impact is the multiplier effect, which helps to determine tourism's total economic impact and comprises three parts: direct spending, indirect spending, and induced spending (Heilbrun \& Gray, 2001:345, 346; Hughes, 2000:174; Vazques, 2001:20).

Socio-economic research indicates economic growth, additional employment, the improvement of host town identity and image, improved resident-tourist relations and cultural opportunities, as well as increased community involvement (Shone \& Parry, 2004:54, Walpole \& Goodwin, 2000:559, Van Heerden, 2003:39) as positive effects of festivals. The negative social impacts 
could include changes in community identity and image, increases in noise pollution, overcrowding and substance abuse (Tiyce \& Dimmock, 2000:223-229).

Socio-economic research on events and festivals is, according to Van der Merwe (2008:14), scarce, particularly in South Africa. The literature review identified the following related studies: De Beer, Elliffe, Spangenberg and Wheeller (1997) on tourism-led development in Kenya; Mbaiwa (2005) on tourism's impacts on the Okavango Delta; Saayman and Saayman (2006b) on the Addo Elephant National Park in South Africa; Loader (1994:143) and Pelser (2003:164) on conservation in South Africa; and Macleod (2001) on national parks in del Este in the Dominican Republic. No research, however, was found on the socio-economic impact of arts festivals in South Africa.

In order to gain a greater understanding of socio-economic research, the framework developed by Van der Merwe (2008:28) will be used (see FIGURE 2). From the figure, three components are identified: input, process and output. Stakeholders' contributions (input and process) determine the magnitude of the festival's socio-economic impacts (outputs), which can then be divided into social impacts and economic impacts (Saarinen, 2003). This framework also makes provision for external environmental factors that could impinge on or improve the extent of the festival's socio-economic outputs. The key stakeholders (and their contributions to festival hosting) are identified as the host organisation, the local community, sponsors, media, coworkers, visitors and performers (the artists in the case of arts festivals or the sport participants in the case of sport events). According to Goldblatt (2000:6), Allen, et al. (2008:129), Bowdin, Allen, 0'Toole, Harris, and McDonnell (2006:111), and Reid and Arcodia (2002:485), to ensure a successful, sustainable event, it has become crucial for event organisers to identify all stakeholders and meet as many of their needs as possible.

The external environment consists of five areas (FIGURE 2), each with underlying factors that could inhibit or improve the outputs of an event (these factors influence the inputs, processes and outputs of events). These external factors (which cannot be controlled by the event organiser) include social and cultural, competition, technological, economic, and political areas (Slabbert, 2004:64, 199). These aspects could have either positive or negative impacts on an event. By way of illustration, an increase in the price of fuel would decrease a household's disposable income, and so the household will have less money to spend on show-ticket purchases. Hence, a decrease in festival income would follow and the magnitude of the festivalrelated advantage would be less. In brief, then, this research seeks answers with regard to the economic and social benefits derived from this arts festival.

\section{METHOD OF RESEARCH}

In order to achieve the purpose of this research, three surveys were conducted. (This is also a procedure recommended by Edwards (2000) for socio-economic impact studies). The surveys included a community survey (amongst the local residents of Oudtshoorn) to measure the social impacts; a business survey (including permanent local businesses in and around the festival area), and a visitor survey (including non-local festinos) to measure the economic impacts that accrue as a result of the festival. The three different expenditures that could be included in an economic impact study are those of the organising committee, the locals, as well as those of the visitors themselves (Saayman \& Saayman, 2006a:579; Shone \& Parry, 2004:113). To include local expenditure, it needs to be determined if the local residents stay in town especially for the festival rather than visiting elsewhere (Crompton, 1999:18). 


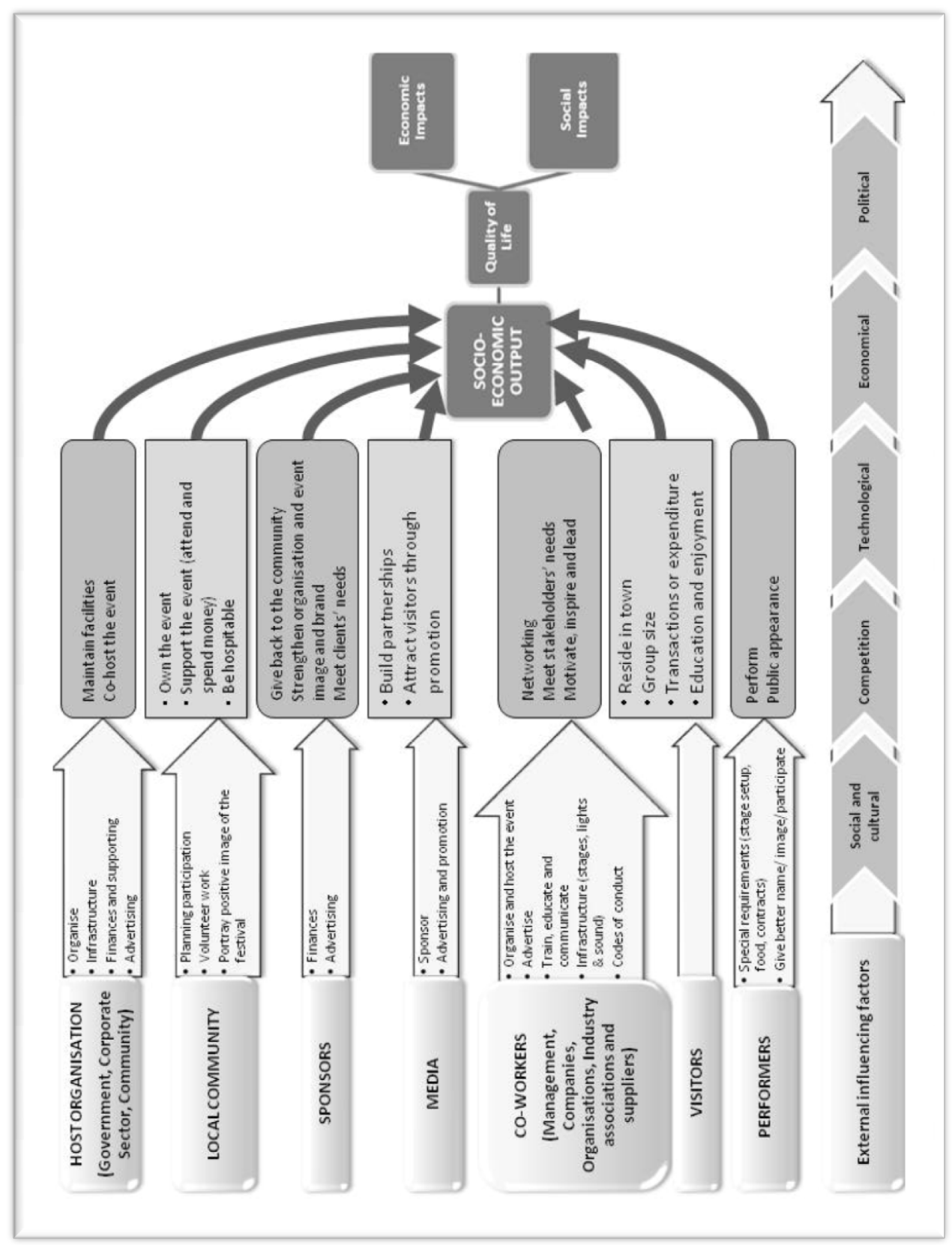

\section{FIGURE 2: Inputs, processes and outputs to event hosting}

Source: Van der Merwe, 2008:40 
This research did not, however, include local expenditure as it could not be determined whether or not locals would stay in town and increase their normal spending patterns at the festival. Nevertheless, by excluding the locals, the researchers were able to determine the total amount of money that was brought in from outside Oudtshoorn.

A descriptive analysis was used to interpret the social impact data, highlighting certain perceptions the community has of the festival. To measure the magnitude of the economic impact of the festival, a structured analytical framework, based on Strydom, Saayman and Saayman (2006), and Saayman and Saayman (2004), was used. This approach entails the calculation and use of a multiplier to determine the economic impact of the additional spending. The multiplier can be derived using various methods, some of the best-known of which include the use of input-output models or sectoral accounting matrices. Research by Walpole and Goodwin (2000), however, concluded that large-scale techniques, such as input-output analysis, are often inappropriate to determine local economic impacts, especially in areas where detailed data is often unavailable. They propose the use of direct estimation from primary sources, obtained through surveys of businesses (supply-side) and tourists (demand-side) to determine the magnitude and distribution of revenue generated by tourism activity. This approach is also followed in this research and the multiplier derived is a Keynesian multiplier based on leakages measured in the business survey. In addition, the framework employed also makes provision for additional leakages based on information received from festival organisers.

Seven postgraduate students were trained in research methodology and thereafter the three surveys were conducted during the festival period of 31 March to 7 April 2007. The business survey was undertaken on 6 April 2007. In most cases, the researchers filled out questionnaires on behalf of respondents, but in some cases questionnaires were handed out and collected later in the day after completion. The social data was coded and input on EPi, SPSS (version 15) and data from all three surveys was coded on Microsoft $^{\odot} \varepsilon_{x c e l}{ }^{\odot}$ and then interpreted by means of descriptive analysis which aided in the comprehension thereof (see Zikmund, 1999:330).

\subsection{The surveys}

\subsubsection{Survey one: Community survey}

The sampling frame for the survey was permanent residents of Oudtshoorn and it was calculated, from census results of 2001 and 1996, that Oudtshoorn has 21173 households (Oudtshoorn Municipality, 2005/2006:6). A stratified sampling procedure was followed $(N=300)$ to ensure that an exact representation of the population was reflected, as indicated by Zikmund (1999:187). Of the 300 questionnaires distributed during the festival period in 2007, 260 were usable. According to the formula set out by Cooper and Emory (1995:207), this sample size is representative of the community.

The census indicated that the Greater Oudtshoorn district, consisting of Oudtshoorn, Dysselsdorp, De Rust and the surrounding rural areas, comprise mainly a coloured (77\%) and white community (15\%). The sample distribution was biased towards the white community $(57 \%)$ followed by the coloured community $(43 \%)$. Since the survey is done yearly, the results of the 2008 survey confirm the results of the current survey. An analysis of the 2008 coloured versus 
white community responses revealed that the responses of the various communities were similar. There was only one item that showed a difference in mean value. ${ }^{\S}$ This provides confidence that the sample results are valid for the community as a whole.

The structured social impact-measuring instrument (questionnaire) that was used was developed by Fredline, Jago and Deery (2003:29), but was adapted to suit the festival's structure. It measured demographics, perceptions, general and specific festival impacts, attitudes, and community support by means of open-ended questions, 3- or 4-point Likert scales, as well as itemised rating scales.

\subsubsection{Survey two: Business survey}

Only permanent Oudtshoorn businesses, located in and around the festival grounds, were included in the business survey, as these are the businesses that are likely to be directly affected by the festival. A total of 117 businesses were identified in the immediate area of the festival, which formed the sampling frame. Not all businesses, however, were willing to complete the questionnaire. By means of convenience sampling, ninety (90) questionnaires were distributed during the research of which 79 were useable.

The questionnaire consisted of close-ended, dichotomous response questions, multiple-choice (with one alternative) and open-ended response questions that measured the aspects of job creation, leakages, crime, and alterations in income occurring during, or because of, the festival.

\subsubsection{Survey three: Visitor survey}

Cooper and Emory (1995:207) state that in an availability sampling within a population (N) of 100000 , a sample size of 384 is recommended. These authors also indicated that the law of diminishing returns applies to sample sizes greater than 300 . Based on the latter, 550 questionnaires were distributed at the festival, of which 512 were usable. Based on the average group size, this survey therefore captures spending and other information of approximately 1 300 festinos.

The questionnaire consisted of 3 sections: Section A captured socio-demographic information, Section $B$ spending information, and section $C$ information on travel motivations. Information derived from sections $A$ and $B$ of the questionnaire was used in this research. The questionnaire included questions with structured, unstructured, open-ended and multiple-choice responses with one alternative.

The questionnaires for both the business and the visitor survey have been used previously in 2003 by Saayman, Saayman and Van Schalkwyk for research on the KKNK.

\subsection{Analytical framework}

The analytical framework that was used to determine the economic impact of the festival by

\footnotetext{
'The item is: "The rights and privilege of residents have ..." where the coloured community indicated an improvement, while the white response indicated a no change. For a full analysis see Adendorff, 2008.
} 
determining the total direct expenditure (DS - equation 5) and total indirect and induced expenditure (TS - equation 6) accruing to the community is displayed in TABLE 1. This framework is adapted from Saayman and Saayman (2004:633) and indicates that $V_{e}$ represents the number of non-local festinos as a proportion of total festinos $V$ and the ratio of non-local festinos is given by $\Phi$ (equation 1 ) - in this case $\Phi=94 \%$. Only non-local festino expenditure was included in these calculations because it could not be determined whether locals would stay in town or not and if they would increase their normal expenditure due to the festival. By excluding the locals, the researchers were able to determine the total amount of money that is injected into the Oudtshoorn economy. $S$ indicates the total expenditure and $S_{i}$ denotes the total expenditure on category $i$ while $\alpha_{i}$ is the average expenditure of a member on expenditure category $i$ (equation 2). $\lambda_{i}$ is the percentage of the expenditure on category $i$ that remains in the local community, the symbol $\beta_{i}$ is used to indicate this percentage (or adaption factor) assigned to each category $i$ (equation 3 ). The expenditures by the event organisers are also brought into consideration: this is represented by $S_{j}$, which has to be multiplied by the relevant adaption factor (equation 4). The organising committee's expenditure is included, since the monies spent are those received from sponsors and stall owners, and the main sponsors to the KKNK, as well as the majority of the stall owners, are non-local companies and individuals.

By substituting equations 1 to 3 into the equation for total spending (equation 4), the total direct expenditure could be calculated (DS - equation 5). By multiplying the DS with the multiplier, which is given by $\mu$, (to bring indirect and induced spending into calculation), the total spending (TS - equation 6) resulting from the festival could be calculated (Saayman \& Saayman, 2004:633).

TABLE 1: System of equations for estimating local economic impact

\begin{tabular}{|c|c|}
\hline Equation Description & Number \\
\hline$V_{e}=\Phi V$ & (1) \\
\hline$S_{i}=V_{e} \alpha_{i}$ & (2) \\
\hline$\lambda_{i}=\beta_{i} \alpha_{i}$ & (3) \\
\hline$S=V_{e} \sum_{i=1}^{n} \lambda_{i}+\sum_{j=1}^{m} S_{j}$ & (4) \\
\hline$D S=\Phi V \Sigma^{n}{ }_{i=1} \lambda_{i}+\sum^{m}{ }_{j=1} \beta_{j} S_{j}$ & (5) \\
\hline$T S=\left(\Phi V \Sigma_{i=1}^{n} \beta_{i} \alpha_{i}+\sum_{j=1}^{m} \beta_{j} S_{j}\right) \mu$ & (6) \\
\hline
\end{tabular}

Source: Adapted from Saayman \& Saayman, 2004:633

\section{RESULTS}

The results are presented in two sections. The first section will discuss the social impact results that were obtained by the community survey. The second section will thereafter discuss the economic impact results that are compiled from the results obtained from both the business and visitor surveys. 


\subsection{Social impacts}

TABLE 2 presents the results of the impact of the festival on the lives of individuals in the community and on the community in general. The concept "happily" indicates an overall positive mindset toward the festival. More than $50 \%$ of the respondents feel that the festival has a positive influence on their personal lives and on the community. The results, however, show a more positive perception with regard to the effect of the festival on the community of Oudtshoorn than on their personal lives.

TABLE 2: Impact on personal lives of respondents and on the Oudtshoorn community

\begin{tabular}{|c|c|c|c|c|c|c|c|}
\hline & $V \varepsilon R Y$ & & & NO & & & $V \varepsilon R Y$ \\
\hline & NEGATIVE & & & EFFECT & & & POSITIVE \\
\hline & -3 & -2 & -1 & 0 & 1 & 2 & 3 \\
\hline $\begin{array}{l}\text { Impact on } \\
\text { personal lives }\end{array}$ & $5 \%$ & $3 \%$ & $3 \%$ & $34 \%$ & $11 \%$ & $24 \%$ & $20 \%$ \\
\hline Impact on & & & & & & & \\
\hline $\begin{array}{l}\text { Oudtshoorn } \\
\text { community }\end{array}$ & $5.5 \%$ & $4.0 \%$ & $4.0 \%$ & $10.0 \%$ & $12.0 \%$ & $28.0 \%$ & $36.5 \%$ \\
\hline
\end{tabular}

Source: Van der Merwe, 2008

TABLE 3: Specific impacts

\begin{tabular}{|c|c|c|c|c|}
\hline STATEMENT & $\begin{array}{c}\text { INCREASE/ } \\
\text { BETTER }\end{array}$ & $\begin{array}{c}\text { DECREASED/ } \\
\text { WORSE }\end{array}$ & NO CHANGE & $\begin{array}{c}\text { DONOT } \\
\text { KNOW }\end{array}$ \\
\hline \multicolumn{5}{|l|}{ Due to the KKNK... } \\
\hline The noise levels in the area... & $35.0 \%$ & $25.0 \%$ & $32.0 \%$ & $8.0 \%$ \\
\hline The job opportunities in Oudtshoorn ... & $62.0 \%$ & $8.0 \%$ & $24.0 \%$ & $6.0 \%$ \\
\hline The variety of things to do in Oudtshoorn ... & $59.0 \%$ & $4.0 \%$ & $28.0 \%$ & $9.0 \%$ \\
\hline The number of people in the area ... & $67.7 \%$ & $6.0 \%$ & $16.7 \%$ & $9.6 \%$ \\
\hline Rowdy behaviour ... & $41.0 \%$ & $16.0 \%$ & $32.0 \%$ & $11.0 \%$ \\
\hline Property value in the area ... & $64.0 \%$ & $3.0 \%$ & $17.0 \%$ & $16.0 \%$ \\
\hline Crime levels... & $35.5 \%$ & $15.1 \%$ & $33.5 \%$ & $15.9 \%$ \\
\hline Community participation in activities ... & $44.0 \%$ & $6.0 \%$ & $29.0 \%$ & $21.0 \%$ \\
\hline Entertainment opportunities ... & $63.0 \%$ & $6.0 \%$ & $24.0 \%$ & $7.0 \%$ \\
\hline Prices of goods and services ... & $56.0 \%$ & $12.0 \%$ & $21.0 \%$ & $11.0 \%$ \\
\hline Community pride towards Oudtshoorn ... & $56.0 \%$ & $9.0 \%$ & $25.0 \%$ & $10.0 \%$ \\
\hline General cost of living ... & $51.0 \%$ & $10.0 \%$ & $31.0 \%$ & $8.0 \%$ \\
\hline Litter in the area... & $43.0 \%$ & $18.0 \%$ & $31.0 \%$ & $8.0 \%$ \\
\hline
\end{tabular}


Van der Merwe, Saayman \& Saayman

\begin{tabular}{|c|c|c|c|c|}
\hline STATEMENT & $\begin{array}{l}\text { INCREASE/ } \\
\text { BETTER }\end{array}$ & $\begin{array}{l}\text { DECREASED/ } \\
\quad \text { WORSE }\end{array}$ & NO CHANGE & $\begin{array}{l}\text { DONOT } \\
\text { KNOW }\end{array}$ \\
\hline Damages to the area ... & $25.2 \%$ & $12.0 \%$ & $40.4 \%$ & $22.4 \%$ \\
\hline Opportunities to meet new people ... & $74.0 \%$ & $5.0 \%$ & $14.0 \%$ & $7.0 \%$ \\
\hline Opportunities for local businesses ... & $67.7 \%$ & $3.6 \%$ & $15.5 \%$ & $13.1 \%$ \\
\hline $\begin{array}{l}\text { The number of tourists who visit } \\
\text { Oudtshoorn throughout the year ... }\end{array}$ & $78.0 \%$ & $5.0 \%$ & $6.0 \%$ & $11.0 \%$ \\
\hline Excessive alcohol and/or drug use ... & $51.0 \%$ & $13.0 \%$ & $22.0 \%$ & $14.0 \%$ \\
\hline $\begin{array}{l}\text { The number of people who permanently } \\
\text { move to Oudtshoorn or buy holiday houses } \\
\text {... }\end{array}$ & $46.0 \%$ & $2.0 \%$ & $17.0 \%$ & $35.0 \%$ \\
\hline Funding for community activities ... & $38.0 \%$ & $9.0 \%$ & $22.0 \%$ & $31.0 \%$ \\
\hline The rights and privileges of residents ... & $24.0 \%$ & $13.0 \%$ & $43.0 \%$ & $20.0 \%$ \\
\hline $\begin{array}{l}\text { Skills levels for event management in } \\
\text { Oudtshoorn... }\end{array}$ & $49.0 \%$ & $7.0 \%$ & $19.0 \%$ & $25.0 \%$ \\
\hline \multicolumn{5}{|l|}{ During the KKNK, } \\
\hline The availability of parking ... & $22.0 \%$ & $57.0 \%$ & $17.0 \%$ & $4.0 \%$ \\
\hline Traffic congestions ... & $38.0 \%$ & $35.0 \%$ & $20.0 \%$ & $7.0 \%$ \\
\hline The turnover of local businesses ... & $68.0 \%$ & $5.0 \%$ & $9.0 \%$ & $18.0 \%$ \\
\hline
\end{tabular}

Source: Van der Merwe, 2008

TABLE 3 indicates that $78 \%$ of the respondents see the fact that more tourists visit Oudtshoorn throughout the year as an advantage. Other social impacts indicated include increased opportunities to meet new people (74\%), entertainment opportunities (63\%), and the number of people in the area $(67.7 \%)$. Some factors of an economic nature measured during the community survey indicate that $62 \%$ of the respondents think that the festival creates job opportunities. Sixty four percent indicated that property value has increased, $67.7 \%$ think the festival provides opportunities for businesses and $68 \%$ think the turnover of local businesses shows a positive impact because of the KKNK. These indications are in correlation with what many authors said when they stated that one of a festival's positive impacts is that it facilitates the flow of money into the region (Auld \& McArthur, 2003:192; Heilbrun \& Gray, 2001:357; Getz, 1997:51; Saayman, 2001:84; Yeoman, et al., 2004:33).

The negative impacts (as indicated by respondents) in TABLE 3 are the following: $57 \%$ indicate that the decrease in availability of parking is a negative aspect, and $35 \%$ indicate that they consider the traffic congestion as a negative impact. Douglas, Douglas and Derret (2001:34) and Hughes (2000:45) stated that overcrowding is a general negative aspect present at festivals, and Andereck, Valentine, Knopf and Vogt (2005) found similar results. Fifty-six percent of the respondents see the price increases on goods and services during the festival as a disadvantage - this relates to the $51 \%$ who indicated that the cost of living increases during the festival. Thirteen percent indicate that alcohol and drug use increases during the festival, but $51 \%$ indicate that the increase is better (that is, less) than in previous festivals. 
Thus, from the table it is clear that there are far more positive than negative effects resulting from the festival. The negative effects are temporary, and are mostly restricted to the period of the festival only. In contrast, the positive effects have largely long-term influences.

\subsection{Economic impacts}

The business survey reveals that $75 \%$ of businesses experience an increase in sales due to the festival. Yet an average of $76 \%$ of stock is bought outside Oudtshoorn, which diminishes the value of the additional sales to Oudtshoorn. It is also noteworthy that the festival leads to additional employment, albeit temporary, since $42 \%$ of businesses indicate that they employ additional people during the festival.

The total economic impact of the event was calculated by combining results from the visitor and business survey, using the figures of total visitor and festival organisers' expenditure, bringing relevant adaption factors into calculation to account for leakages and, finally, by multiplying with the multiplier (see the analytical framework, TABLE 1).

Average and total visitor expenditure per respondent (with financial responsibility of 2.75 other festinos) is indicated in TABLE 4. The average number of tickets bought per visitor group is 10, which is calculated by dividing the average amount $(R 620,99)$ of money spent on tickets per visitor group with financial responsibility of 2.75 other festinos, by the average ticket price (R62). A total of 133856 tickets were sold: thus the number of visitor groups to the festival is 13 386 and by multiplying this by the average group size (2.75), the number of visitors to the festival is calculated to be 36811 .

Hughes (2000:174) stated, "The expenditure of foreign tourists is an injection into a country. It is additional money which is an inflow ... which may create extra income and employment in the country concerned". This highlights the important point that events only have considerable economic impacts when new money enters the local economy and the multiplier effect takes place (Dwyer, et al., 2000:32; Dwyer, Forsyth \& Spurr, 2006:317).

TABLE 4 indicates that the average total expenditure is R3 719,98 , and the total direct expenditure by festinos is R46.8 million, which could also be calculated by substituting relevant amounts into equation (2) indicated in TABLE 1. Most money was spent on accommodation (R955,22 per group, total: R12 million) and transport to the KKNK (R618,37: R7.78 million). The "other" expenditure is the lowest category and includes CD and DVD purchases, as well as magazine subscriptions.

The economic impact of the festival depends significantly on purchases made in Oudtshoorn and not elsewhere. When considering show tickets that are bought, it must be borne in mind that many tickets are bought outside the regional boundaries of Oudtshoorn, over the internet, or from Computicket in the visitors' hometowns. Therefore, the ticket sales figure needs to be adapted due to VAT, commission and artist salaries, as the National Treasury (situated in Pretoria) receives the VAT, Computicket (situated in Johannesburg) receives the commission and Oudtshoorn is not the hometown of the majority of the artists. The adaptation ( $\beta_{i}$ in equation 6 ) factor for ticket sales is calculated on $24 \%$ (based on information received from organisers), meaning that Oudtshoorn receives the revenue from only $24 \%$ of all ticket sales. 
TABLE 4: Visitor expenditure

\begin{tabular}{|c|c|c|}
\hline Category & $\begin{array}{l}\text { Expenditure per respondent } \\
\text { with financial responsibility } \\
\text { of } 2.75 \text { others }\end{array}$ & Total expenditure \\
\hline Accommodation & $\mathrm{R} 955,22$ & R12 019446,42 \\
\hline Food and restaurants & $\mathrm{R} 338,13$ & R4 254659,05 \\
\hline Alcoholic drinks & $\mathrm{R} 287,67$ & R3 619725,46 \\
\hline Non-alcoholic drinks & $\mathrm{R} 182,23$ & R2 292983,52 \\
\hline Shows & $\mathrm{R} 538,73$ & R7 345021,52 \\
\hline $\begin{array}{l}\text { Retail shopping (excluding food and } \\
\text { drinks) }\end{array}$ & $\mathrm{R} 201,76$ & R2 538727,74 \\
\hline $\begin{array}{l}\text { Shopping at stalls (excluding food and } \\
\text { drinks) }\end{array}$ & R412,73 & R5 193344,07 \\
\hline $\begin{array}{l}\text { Amusement parks and adventure } \\
\text { activities }\end{array}$ & $R 32,21$ & R405 295,50 \\
\hline Transport to KKNK & $\mathrm{R} 618,37$ & R7 780893,49 \\
\hline Transport at KKNK & $\mathrm{R} 67,16$ & $\mathrm{R} 845068,17$ \\
\hline Parking & $\mathrm{R} 27,04$ & R340 241,86 \\
\hline Other & $\mathrm{R} 13,64$ & $R 171630,88$ \\
\hline TOTALS & R3 719,89 & R46 807037,70 \\
\hline
\end{tabular}

Source: Authors'own calculations

Few Oudtshoorn locals own exhibiting stalls at the festival. The festival committee indicated that local residents own approximately $21 \%$ of all stalls and non-locals own some of the food stalls. Thus, the adaptation factor for souvenirs is $21 \%$ while for food it is estimated as $90 \%$ (because all restaurants are based in Oudtshoorn, but just $10 \%$ of the food stalls are owned by non-locals). For transport, the adaptation factor it is calculated at $40 \%$ (since it is believed that many festinos fill their vehicles with fuel in their hometowns before leaving for the festival and perhaps refill again in Oudtshoorn before leaving for home). After these adaptations have been brought into consideration, the total direct expenditure equals R31.4 million.

Another form of additional expenditure that takes place in Oudtshoorn is spending by festival organisers. The festival's organising committee uses funds received from sponsors and stall space renters to organise the festivals (and both of these are cash injections into the town). The festival's organising committee expenses include the related advertising, hiring of equipment, venues, contractors, personnel, and technicians. Artists' accommodation and remuneration of organisers also need to be paid. To proxy organiser spending, the amounts received from sponsors and exhibitors' stall hire are used, which totalled R10.18 million. The festival committee indicated that $80 \%$ of all hired personnel and equipment are Oudtshoorn residents (which is accounted for by $\left(\beta_{\mathrm{j}}\right)$ in equations 5 and 6) (Slabbert, et al., 2007:40). If the organising committee's festival-related expenditure is brought into consideration (equation 5 ) while considering the $20 \%$ leakage, the expenditure totals R39.6 million. 
TABLE 5 indicates leakages per business sector and the average leakage is calculated as $63.43 \%$. This leakage percentage was used to calculate the multiplier of 1.58 (TABLE 6). This multiplier is higher than the multipliers indicated by Saayman and Saayman (2004) for the festival of 2003 (when it was 1.43); thus it should be seen as a best-case scenario. The increase in the multiplier size could be ascribed to the fact that, in 2007, a larger percentage of the stall owners were locals, or that visitors spent more in 2007 or that the leakages might have decreased (Slabbert, et al., 2007:40). The implementation of this multiplier (equation 6), represented by symbol $\mu$, brings the total economic impact (TS) of the festival on Oudtshoorn to R62.5 million.

TABLE 5: Average leakages per business sector

\begin{tabular}{lcc}
\hline Type of business & Number of respondents & $\begin{array}{c}\text { Average percentage of stock } \\
\text { bought outside Oudtshoorn }\end{array}$ \\
\hline Accommodation & 15 & 12.00 \\
Curio & 4 & 63.75 \\
Food & 21 & 48.81 \\
Retail & 23 & 70.17 \\
Transport & 6 & 86.00 \\
Wholesaler & 3 & 91.67 \\
Manufacturing & 1 & 75.00 \\
Services & 5 & 60.00 \\
\hline
\end{tabular}

Source: Van der Merwe, 2008

The effect of a smaller multiplier is indicated along with the higher multiplier of 2007 in TABL 6 to give a more conservative prediction of the total economic impact that accrues to Oudtshoorn due to the festival. TABLE 6 gives a summary of all the above calculations and indicates the total direct and indirect expenditure. This table does, however, exclude all expenses carried by the local authorities or residents in preparation for the festival.

\section{IMPLICATIONS}

This research confirms that the KKNK has a significant socio-economic impact on the community of Oudtshoorn. Firstly, this is highlighted by the fact that the event generated approximately R62.5 million in 2007, even when improvements in infrastructure and the marketing value of the event for the town as a tourist attraction were excluded. Therefore this research supports findings by Walpole and Goodwin (2000), Getz (1997), Loots (2006) and Kim, et al. (2006) that events such as these have positive socio-economic impacts. Secondly, it demonstrates that the community in general indicate this event having a positive impact on their quality of life which, according to Glasson and Hearney (1993), is the essence of a socio-economic impact analysis. Yet, the impact is perceived to be bigger for the community as a whole than for the individual person. These findings correlate well with literature on the impacts of events (see Gursoy, et al., 2002; Gursoy \& Kendall, 2006, Shone \& Parry, 2004), as well as research conducted by Macleod (2001) on national parks in Indonesia. 
TABLE 6: Total economic impact

\begin{tabular}{|c|c|c|}
\hline Total non-local festino expenditure & \multicolumn{2}{|c|}{ R46 807037,70} \\
\hline \multicolumn{3}{|l|}{ Adaption Factors $\left(\beta_{\mathrm{i}}\right)$ : } \\
\hline Show tickets & \multicolumn{2}{|c|}{$24 \%$} \\
\hline Souvenirs & \multicolumn{2}{|c|}{$21 \%$} \\
\hline Food & \multicolumn{2}{|c|}{$90 \%$} \\
\hline Transport & \multicolumn{2}{|c|}{$40 \%$} \\
\hline Total Direct non-local festino expenditure & \multicolumn{2}{|c|}{ R31 436806,63} \\
\hline Organisers expenditure $\left(\beta_{\mathrm{j}}=0.8\right)$ & \multicolumn{2}{|c|}{ R8 144000,00} \\
\hline \multirow[t]{2}{*}{ Total Direct Expenditure } & \multicolumn{2}{|c|}{ R39 580806,63} \\
\hline & SCENARIO I & SCENARIO 2 \\
\hline Multiplier & 1.43 & 1.58 \\
\hline Indirect impact & R17 019746,85 & R22 956867,85 \\
\hline TOTAL IMPACT & R56 600553,48 & R62 537674,48 \\
\hline
\end{tabular}

Source: Authors'own calculations

Thirdly, to increase the socio-economic benefits of the festival, the organisers should focus on meeting more of the stakeholders' needs, as was indicated by Allen, et al. (2008). This is especially true in the case of the local community that hosts the event, and sponsors of additional funding for the event. Research by Saayman and Saayman (2004) showed that the event sponsors spend has a significant influence on the magnitude of the economic impact. In fact, their research indicated that arts festivals in South Africa cannot survive without such sponsorships. Added to this, Van der Merwe (2008) showed that almost all stakeholders do some form of marketing or advertising for the event (see FIGURE 2). In order to address this, stakeholders should be represented in the planning and management committee of the festival. The latter is regarded by Streuders (2008) as vital for community participation. Therefore, it would be advisable to determine the needs, perceptions, and expectations of different stakeholders with regard to their role and function in the event.

Fourthly, to improve the social impact of the festival, it has become paramount to increase the participation of the local community in terms not only of the planning of the event, but also in terms of production of shows and exhibitions at the event. Again this research confirms findings by Loader (1994) and Pelser (2003). Furthermore, it is also important to maintain communication on a continuous basis to members of the community in order to keep them abreast of what is happening throughout the year, and not just the few weeks prior to the event. The reason why individuals do not see or perceive the festival to contribute to their personal quality of life might be ignorance caused by a lack of communication. This supports findings by Streuders (2008) and Allen, et al. (2008). These researchers concur that if residents are better informed of the value of the event, they might well be more positive about the festival.

Fifthly, this research confirms research by Saayman and Saayman (2006a), who called attention to high leakages in small towns in South Africa. Therefore the community and businesses should 
be encouraged to become more involved in selling products and services at the festival. If this can be achieved, leakages will be decreased, according to Hughes (2000) and Heilbrun and Gray (2001), which in turn will increase the economic benefit derived from the event, leading to additional social improvements.

Lastly, an increase in visitor length of stay and ticket sales would increase the amount generated by the festival. The length of stay can be increased by new initiatives, such as selling packages at an attractive price, rather than just individual tickets.

\section{CONCLUSION}

The aim of this article was to demonstrate the socio-economic impact of the KKNK on Oudtshoorn. This research is the first of its kind on events in South Africa, and illustrates the importance of events as tourist attractions, together with the diverse impacts and advantages they hold. The findings assist researchers to form a greater understanding of the socioeconomic impact of the largest arts festival in South Africa. The festival proved to have a significant socio-economic impact on the community, especially in terms of economic value. It was indicated that stakeholders support events and festivals, due to the possible positive impacts the festival has on the local community in terms of developments and economic boosts. Events cannot take place without stakeholder inputs; thus event organisers should attempt to cater to all stakeholder groups, as far as possible, to ensure their participation and support and by so doing, ensuring a more sustainable event with increased socio-economic benefits. The results recorded by this research project show that events can be used to improve the quality of life of host communities, as a collective. It is then up to the community to extract as much benefit as possible from the event.

The influx of tourists into a community brings money into the community. This leads to economic increases and, from this, new developments take place that could change the quality of life of residents. The positive effects from events include increased tourist numbers, leading to job creation, business opportunities, increased incomes, entertainment opportunities, and community pride. Leakages do, however, take place. This impinges upon the magnitude of the economic impact and thus the social impact as well. Accordingly, event organisers should make a joint effort with all stakeholders and local businesses to decrease leakages to gain maximum benefit and socio-economic improvements. Further research at other arts festivals should be conducted to gain a greater understanding of the socio-economic impacts of these events as well as to facilitate comparison between different events.

\section{REFERENCES}

Adendorff, $\varepsilon$. (2008). The social impact of the Klein Karoo National Arts Festival: A Comparison between White and Coloured Communities. Unpublished M.Com Dissertation. Potchefstroom: NorthWest University.

Allen, J., 0'Toole, W., Harris, R. \& McDonnell, I. (2005). Festival and Special Event Management, $3^{\text {rd }}$ edition. Queensland: John Wiley \& Sons Australia.

Allen, J., O'Toole, W., Harris, R. \& McDonnell, I. (2008). Festival and Special Event Management, $4^{\text {th }}$ edition. Queensland: John Wiley \& Sons Australia. 
Andereck, K. L., Valentine, K. M., Knopf, R. C. \& Vogt, C. A. (2005). Residents' perceptions of community tourism impacts. Annals of Tourism Research, 32(4), pp. 1056-1076.

Anon. (2006). Section on socio-economics newsletter of the Association of American Law Schools. Journal of law and socio-economics, 27, Dec. http://journaloflawandsocioeconomics.com. Accessed on 21 January 2007.

Auld, T. \& Mcarthur, S. (2003). Does event-driven tourism provide economic benefits? A case study from the Manawatu region of New Zealand. Tourism economics, 9(2), pp. 191-201.

Bowdin, G. A. J., Allen, J. A., O’Toole, W., Harris, I. \& Mcdonnell, I. (2006). Events management. Amsterdam: Elsevier.

Cape Town Accommodation \& Travel. (2007). Accommodation map search - Western Cape. http://www.discoverthecape.com/map-s-western-cape.html. Accessed on 80 ctober 2008.

Cooper, D. R. \& Emory, W. (1995). Business research methods. Chicago, IL: Irwin.

Crompton J. L. (1999). Measuring economic impact. Working paper, http://www.rpts.tamu.edu/faculty/Crompton/Crompton/Books/7.pdf. Accessed on 8 0ctober 2008.

Cruywagen, દ. (2002). Report on the Klein Karoo National Arts Festival (KKNK) 2002. South African Theatre Journal, 16, pp. 190-191.

De Beer, G. R. M., Elliffe, S. P., Spangenberg, P. P. \& Wheeller, B. (1997). The socio-economic impact of tourism led development: The case of the Kenyan coastline from Malindi to Mombasa. Johannesburg: Development Bank of Southern Africa.

Delamere, T. A. (1998). Development of a scale to measure local resident attitudes toward the social impact of community festivals. Unpublished D.Phil Thesis. Edmonton: University of Alberta.

Douglas, N., Douglas, N. \& Derret, R. (eds.) (2001). Special interest tourism, context and cases. Brisbane: John Wiley \& Sons Australia, Ltd.

Dwyer, L., Mellor, R., Mistilis, N. \& Mules, T. (2000). A framework for evaluating and forecasting the impacts of special events. In: Allen, J., Harris, R., Jago, L. K. \& Veal, A. J. (eds.) Events beyond 2000: Setting the agenda. Proceedings of conference on event evaluation, research and education held in Sydney in July 2000. Sydney: Australian Centre for Event Management. (pp. 31-45)

Dwyer, L., Forsyth, P. \& Spurr, R. (2006). Economic evaluation of special events. In: Dwyer, L. \& Forsyth, P. (eds.) International handbook on the economics of tourism. Northampton, MA: Edward Elgar. (pp. 316-355)

Edwards, M. (2000). Community guide to development impact analyses. http://www.lic.wisc.edu/shapingdane/facilitation/all_resources/impacts/analysis_socio.htm. Accessed on 19 January 2007.

Fauzi, A. \& Buchary, E. S. (2002). A socio-economic perspective of environmental degradation at Kepulauan Seribu Merine National Park, Indonesia. Coastal Management, 30, pp. 167-181.

Fredline, $\varepsilon .$, Jago, L. \& Deery, M. (2003). The development of a generic scale to measure the social impacts of events. Event management, 8, pp. 23-37.

Getz, D. (1997). Event management \& event tourism. New York: Cognizant Communication Corporation.

Glasson, J. \& Heaney, D. (1993). Socio-economic impacts: The poor relations in British environmental impact statements. Journal of environmental planning and management, 36(3), pp. 335-343. 
Goldblatt, J. (2000). A future for event management: The analysis of major trends impacting the emerging profession. In: Allen, J., Harris, R., Jago, L.K. \& Veal, A.J. (eds.) Events beyond 2000: Setting the agenda. Proceedings of conference on event evaluation, research and education held in Sydney in July 2000. Sydney: Australian Centre for Event Management. (pp. 2-9)

Gursoy, D., Jurowski, C. \& Uysal, M. (2002). Resident attitudes: A structural approach. Annals of tourism research, 29(1), pp. 79-105.

Gursoy, D. \& Kendall, K. W. (2006). Hosting mega events: modelling locals' support. Annals of tourism research, 33(3), pp. 603-623.

Heilbrun, J. \& Gray, C. M. (2001). The economics of art and culture. $2^{\text {nd }}$ edtion. Cambridge: Cambridge University.

Hughes, H. (2000). Arts, entertainment and tourism. Oxford: Butterworth-Heinemann.

Kim, H. J., Gursoy, D. \& Lee, S. (2006). The impact of the 2002 World Cup on South Korea: Comparisons of pre- amd post-games. Tourism Management, 27, pp. 86-96.

Kitshoff, H. (2004a). Claiming cultural festivals: playing for power at the Klein Karoo Nasionale Kunstefees (KKNK). South African theatre journal, 18, pp. 65-81.

Kitshoff, H. (2004b). Klein Karoo Nasionale Kunstefees (KKNK) - Oudtshoorn, 3-11 April 2004. South African Theatre Journal, 18, pp. 237-241.

Loader, J. A. (1994). National Parks and social involvement - an argument. Koedoe, 8, pp. 23-37.

Loots, $\varepsilon$. (2006). The 2010 Soccer World Cup: An economic and socio-economic perspective.

DiscourseDiskoers, 34(2), pp.14-20.

Macleod, D.V.L. (2001). Parks or People: National Parks and the case of Del Este, Dominican Republic. Progress in Development Studies, 1(3), pp. 221-235.

Maenning, W. (2007). One year later: A re-appraisal of the economics of the 2006 Soccer World Cup. North American Association of Sports Economists. IADE/NAASE Working Paper Series, Paper No. 07-25. July.

Mbaiwa, J. E. (2005). Enclave tourism and its socio-economic impacts in the Okavango Delta, Botswana. Tourism management, 26(2), pp. 157-172.

McKercher, B., Mei, W. S. \& Tse, T. S. M. (2006). Are short duration cultural festivals tourist attractions? Journal of Sustainable Tourism, 14(1), pp. 55-66.

Oudtshoorn Municipality. (2005/2006). Integrated development plan. http://www.oudtmun.co.za/mfma.html. Accessed on 27 August 2007.

Pelser, A. (2003). Omgewingsbewaring in ' $n$ nuwe era: ' $n$ Nis vir die geestes- en sosiale wetenskappe. Tydskrif vir Geesteswetenskappe, 43(3\&4), pp. 164-176.

Quinn, B. (2006). Problematising "festival tourism": Arts festivals and sustainable development in Ireland. Journal of sustainable tourism, 14(3), pp. 288-306.

Reid, S. \& Arcodia, C. (2002). Understanding the role of the stakeholder in event management. In: Jago, L., Deery, M., Harris, R., Hede, A. \& Allen, J. (eds.) Events and place making. Proceedings of international event research conference held in Sydney in July 2002. Sydney: Australian Centre for Event Management. (pp. 479-515) 
Saarinen, J. (2003). The regional economics of tourism in Northern Finland: The socio-economic implications of recent tourism development and future possibilities for regional development. Scandanavian Journal of Hospitality and Tourism, 3(2), pp. 91-113.

Saayman, M. (ed.) (2001). An introduction to sports tourism and event management. Potchefstroom: Leisure consultants and publications.

Saayman, M. \& Saayman, A. (2004). Economic impact of cultural events. South African journal of economic and management sciences, 7(4), pp. 629-641.

Saayman, M. \& Saayman, A. (2006a). Does the location of arts festivals matter for the economic impact? Papers in regional science, 85(4), pp. 569-584.

Saayman, M. \& Saayman, A. (2006b). Creating a framework to determine the socio-economic impacts of national parks in South Africa: A case study of the Addo Elephant National Park. Tourism economics, 12(4), pp. 619-633.

Saayman, M., Saayman, A. \& Van Schalkwyk, C. (2003). Die ekonomiese impak van besoekers aan die Klein Karoo Nasionale Kunstefees te Oudtshoorn. Instituut vir Toerisme en Vryetydstudies: Potchefstroom.

Shone, A. \& Parry, B. (2004). Successful event management, $2^{\text {nd }}$ edition. London: Thomson.

Slabbert, દ. (2004). An integrated tourism model for cultural events. Unpublished D.Phil Dissertation. Potchefstroom: North-West University.

Slabbert, E., Saayman, M., Saayman, A. \& Viviers, P. (2007). Die socio-ekonomiese impak van besoekers aan die ABSA KKNK. Potchefstroom: Instituut vir Toerisme en Vryetydstudies.

Streuders, C. (2008). Communication efficacy of Karoo National Park. Unpublished M.Com Dissertation. Potchefstroom: North-West University.

Strydom, A. J., Saayman, A. \& Saayman, M. (2006). The economic impact of the Volksblad Arts Festival. Acta Commercii, pp. 87-98.

Tiyce, M. \& Dimmock, K. (2000). Nimbin mardi grass festival: the impacts. In Allen, J., Harris, R., Jago, L. K. \& Veal, A. J. Events beyond 2000: Setting the agenda: Proceedings of conference on event evaluation, research and education held in Sydney in July 2000. Sydney: Australian Centre for Event Management, pp. 222-230.

Van Der Merwe, L. H. (2008). The socio-economic impact of the Klein Karoo National Arts Festival. Unpublished M.Com Dissertation. Potchefstroom: North-West University.

Van Heerden, A. (2003). The economic impact of the Aardklop National Arts Festival in Potchefstroom. Unpublished M.Com Dissertastion. Potchefstroom: Potchefstroom University for Christian Higher Education.

Vazques, J. J. (2001). Socio-economical and ecological effects of tourism: A structural analysis of the lake George watershed region. Unpublished D.Phil Thesis. New York: Rensselaer Polytechnic Institute, Troy.

Walpole, M. J. \& Goodwin, H. J. (2000). Local economic impacts of dragon tourism in Indonesia. Annals of Tourism Research, 27(3), pp. 559-576.

Yeoman, I., Robertson, M., Ali-Night, J., Drummond, S., \& Beattie-Mcmahon, U. (2004). Festival and events management, an international arts and culture perspective. Oxford: Butterworth-Heinemann.

Zikmund, W. G. (1999). Essentials of marketing research. Orlando, FL: Harcourt Brace. 